\title{
PENGARUH KONSENTRASI ISOPROPANOL TERHADAP KARAKTERISTIK KARBOKSIMETIL SELULOSA DARI BATANG PISANG
}

\section{THE INFLUENCE OF ISOPROPANOL CONCENTRATION ON CHARACTERISTICS OF CARBOXIMETHYL CELLULOSE FROM BANANA STEM}

\author{
Ridwan Santoso ${ }^{1}$, Edwin Azwar ${ }^{2}$ \\ Jurusan Teknik Kimia, Fakultas Teknik Universitas Lampung \\ Email : ridwan.santoso11@gmail.com
}

Dikirim 24 Juni 2020, Direvisi 12 November 2020, Disetujui 24 November 2020

\begin{abstract}
Abstrak: Pada penelitian ini terdiri dari 5 tahap yaitu persiapan bahan baku, isolasi selulosa, alkalisasi, karboksimetilisasi, dan pemurnian. Tahap persiapan bahan baku yaitu serbuk batang pisang diayak pada mesh 60. Selanjutnya, isolasi selulosa batang pisang dilakukan dengan asam formiat $90 \%$ dengan kecepatan pengadukan $300 \mathrm{rpm}$ selama 180 menit pada suhu $100{ }^{\circ} \mathrm{C}$. Selulosa yang dihasilkan selanjutnya dialkalisasi dengan menggunakan $\mathrm{NaOH}$ 15\% dan variasi konsentrasi pelarut isopropanol 70\%, 80\%, 90\% dan $100 \%$ didalam waterbath shaker $100 \mathrm{rpm}$ selama 60 menit pada suhu 300C. Tahap berikutnya yaitu karboksimetilasi antara alkali selulosa dan asam trikloroasetat selama 180 menit pada suhu 550C didalam waterbath shaker 100 rpm. Pada tahap pemurnian digunakan asam asetat glasial dan etanol untuk menghilangkan produk samping yang tidak diinginkan. Selanjutnya dikeringkan pada suhu $60{ }^{\circ} \mathrm{C}$. Hasil penelitian diperoleh karakteristik CMC dengan nilai derajat substitusi (DS) tertinggi sebesar 0,8 pada komposisi isopropanol 100\%, kemurnian tertinggi 99,7\%, dan $\mathrm{pH} 4,8$.
\end{abstract}

Kata kunci: Alkalisasi, Derajat Substitusi, Isopropanol, Karboksimetil Selulosa

\begin{abstract}
In this study consists of 5 stages, namely preparation of raw materials, cellulose isolation, alkalization, carboxymethylization, and purification. The raw material preparation stage is banana stem powder sieved at mesh 60. Furthermore, cellulose isolation of banana stems is carried out with 90\% formic acid with a stirring speed of $300 \mathrm{rpm}$ for 180 minutes at $100^{\circ} \mathrm{C}$. Alkalised using $15 \% \mathrm{NaOH}$ and varying concentrations of 70\%, 80\%, 90\% and 100\% isopropanol solvents in a $100 \mathrm{rpm}$ waterbath shaker for 60 minutes at $30^{\circ} \mathrm{C}$. The next step is carboxymethylation between alkali cellulose and trichloroacetic acid for 180 minutes at $55^{\circ} \mathrm{C}$ in a 100 rpm waterbath shaker. At the purification glacial acetic acid and ethanol are used to remove unwanted byproducts. The results characteristics with the highest degree of substitution value of 0.8 in the composition of $100 \%$ isopropanol, the highest purity of $99.7 \%$, pH 4.8 and $5 \%$ moisture content.
\end{abstract}

Keywords: Alkalization, Carboxymethyl Celulose, Degree of Substitution, Isopropanol

\section{PENDAHULUAN}

Karboksimetil selulosa merupakan merupakan eter polimer selulosa linear dan berupa senyawa anion, yang bersifat biodegradable, tidak berwarna, tidak berbau, tidak beracun, butiran atau bubuk yang larut dalam air namun tidak larut dalam larutan organik (Alia Badra Pitaloka, dkk., 2015). Menurut BPS (2016), penggunaan karboksmeril selulosa setiap tahunnya mengalami peningkatan dan tercatat hingga 2016 data impor mencapai $552.532 \mathrm{~kg}$ perbulannya. Hal ini menunjukkan bahwa kebutuhan masyarakat bahwa kebutuhan masyarakat terhadap karboksimetil selulosa sangat tinggi (Ayuningtiyas, dkk., 2017).

Karboksimetil selulosa secara luas digunakan dalam bidang pangan, industri dan formulasi. Khusus bidang pangan, karboksimetil selulosa dimanfaatkan sebagai stabilizer, thickner, adhesive, dan emulsifier. Karboksimetil selulosa pada berbagai industri dimanfaatkan pada detergen, cat, keramik, tekstil, kertas dan makanan. Fungsi karboksimetil selulosa pada bidang formulasi adalah sebagai 
pengental, penstabil emulsi atau suspensi dan bahan pengikat (Hasibuan, 2016).

Selama ini pisang banyak dimanfaatkan pada buah dan daunnya, sedangkan batang pisang kurang banyak dimanfaatkan sehingga menjadi limbah pada lingkungan. Kandungan selulosa yang tinggi cukup tinggi ini bisa dimanfaatkan sebagai alternatif pembuatan karboksimetil selulosa. Kandungan selulosa batang pisang sebesar 63-64 \%, hemiselulosa 20\% dan lignin $5 \%$ (Roliadi dan Anggraini, 2010). Selulosa batang pohon pisang berpotensi digunakan sebagai bahan baku sintesis karboksimetil selulosa (Mohapatra, dkk, 2010).

Karboksimetil selulosa adalah turunan selulosa yang larut dalam air yang dimodifikasi yang dihasilkan oleh reaksi selulosa dengan asam alkali dan monokloroasetat, menggunakan pelarut organik, dalam kondisi heterogen (A.B.M.F. Alam, dkk., 2013). Diantara beberapa faktor yang mempengaruhi karakteristik karboksimetil selulosa yaitu konsentrasi pelarut (Jia Fang, dkk., 2016).

Peran pelarut yang digunakan dalam proses alkalisasi adalah kemampuannya untuk melarutkan zat eterifikasi, seperti asam natrium monokloroasetat (NaMCA), dan mengembangkan selulosa sehingga membuat zat eterifikasi lebih mudah untuk memasuki struktur selulosa. Adanya pengaruh konsentrasi pelarut terhadap karakteristik karboksimetil selulosa (Fang Jia, dkk., 2016). Sehingga dibutuhkan pelarut dengan konsentrasi yang tepat untuk mendapatkan karakteristik karboksimetil selulosa yang terbaik. Pada proses karboksimetilasi digunakan reagen asam trikloroasetat (Devi dkk, 2014), dimana pada tahap ini terjadi pelekatan gugus karboksilat pada struktur selulosa. Setelah proses sintesis selesai, selanjutnya Carboxymethyl cellulose yang terbentuk dimurnikan.

Pembuatan Karboksimetil Selulosa bisa didapat dari berbagai selulosa tanaman seperti yang dilakukan oleh Mario P. Adinugraha, dkk., (2005) pembuatan karboksimetil selulosa dari selulosa batang pisang (Musa cavendishii LAMBERT), Sekam Jagung (M. Ibrahim H. Mondal, 2015) kulit jeruk (Mukaddes Karatas dan Nurhan Arslan, 2016), tongkol jagung dengan variasi konentrasi pelarut (Jia Fang dkk, 2016), Jerami tebu (Cancido dan Goncalves, 2016), biji salak (Sri Anggrahini, dkk., 2017), Jerami padi (M. Zakir Muzakkar, dkk., 2017), pembuatan karboksimetil selulosa dari kulit pisang kapok dengan variasi temperature dan waktu reaksi (Saputri Ayuningtyas, dkk., 2017) telah dilaporkan oleh banyak peneliti. Akan tetapi masih perlu dilakukan penelitian lebih lanjut sebagai alternatif didalam pembuatan karboksimetil selulosa dengan bahan baku yang tersedia melimpah di Indonesia dan informasi terkait pengaruh penggunaan konsentrasi pelarut terhadap karakteristik karboksimetil selulosa yang dipersyaratkan yaitu Standar Nasional Indonesia (SNI).

Penelitian ini terdiri dari 4 tahap yaitu persiapan bahan baku, ekstraksi selulosa, sintesis CMC (alkalisasi, karboksimetilasi dan purifikasi), dan karakterisasi CMC. Dengan mengacu penelitian Devi Silsia, dkk., (2018) peneliti akan melakukan penelitian dengan menggunakan konsentrasi $\mathrm{NaOH} 15 \%$, menggunakan pelarut isopropanol dan $20 \%$ asam trikloroasetat. Diharapkan dengan memvariasikan konsentrasi isopropanol didapat karakteristik CMC dari selulosa batang pisang yang sesuai dengan parameter SNI (Standar Nasional Indonesia).

\section{LANDASAN TEORI}

Selulosa merupakan senyawa polisakarida yang tidak mudah larut dalam air yang berfungsi sebagai pembentuk sel kulit pada tanaman. Selulosa terdapat pada semua jenis tanaman. Selulosa memiliki rumus kimia yaitu $\mathrm{C}_{6} \mathrm{H}_{10} \mathrm{O}_{5}$, setiap struktur selulosa mengandung 3 grup alkohol hidroksil. Dimana didalam batang pisang terdapat hemiselulosa $6-8 \%$, Lignin 5 - 
$10 \%$, Selulosa $60-65 \%$, Air $10-15 \%$ (Asparani, 2013). Batang pisang dengan kandungan selulosanya yang tinggi sehingga dapat dimanfaatkan sebagai suatu sumber alternatif berupa bahan tambahan pangan yaitu karboksimetil selulosa.

Karboksimetil selulosa merupakan eter polimer selulosa linear dan berupa senyawa anion, yang bersifat biodegradable, tidak berwarna, tidak berbau, tidak beracun, butiran atau bubuk yang larut dalam air namun tidak larut dalam larutan organik. Bahan baku dapat diperoleh dari selulosa yang terkandung dalam tanaman. Karboksimetil selulosa telah banyak digunakan dan memiliki peranan yang penting dalam berbagai aplikasi. Aplikasi karboksimetil selulosa pada makanan, pasta gigi dan obat-obatan digunakan sebagai Extra purified (cellulose gum) (Mondal et al, 2015). Karboksimetil selulosa dapat disintesis dari beragam tumbuhan, yang mengandung selulosa $40-50 \%$, hemiselulosa 25 - 40\% dan lignin 15 - 35\% (Singh, 2012). Sedangkan kandungan selulosa pada batang pisang sebesar 63$64 \%$, hemiselulosa $20 \%$ dan lignin $5 \%$ (Roliadi dan Anggraini, 2010). Karboksimetil selulosa merupakan turunan selulosa yang dibuat dengan menukarkan gugus hidroksil selulosa dengan gugus karboksil yang terkandung dalam natrium kloroasetat dalam kondisi basa.. Karakteristik karboksimetil selulosa berdasarkan SNI 06-3736-1995 ditunjukan oleh tabel 1.

Tabel 1. Standar Mutu Karboksimetil Selulosa di Indonesia

\begin{tabular}{cccc}
\hline \multirow{2}{*}{ No } & \multirow{2}{*}{ Parameter } & \multicolumn{2}{c}{ SNI } \\
& & Mutu I & Mutu II \\
\hline 1 & Kemurnian & $99,50 \%$ & $65,00 \%$ \\
2 & Kandungann & $0,25 \%$ & - \\
& NaCl & & \\
3 & Derajat & $0,7-1,2 \%$ & $0,4-1 \%$ \\
& Substitusi & & $6,0-$ \\
4 & pH Larutan & $6,0-8,0 \%$ & $8,5 \%$ \\
\hline
\end{tabular}

Berdasarkan Tabel 1 diatas, karboksimetil selulosa yang diklasifikasikan sebagai mutu I digunakan dalam industri makanan, obat-obatan dan kosmetik, sedangkan untuk mutu II digunakan dalam industri pertambangan.

Sintesis karboksimetil selulosa meliputi reaksi alkalisasi dan karboksimetilasi dimana reaksi tersebut menentukan karakteristik yang diperoleh (Sri Anggrahini, dkk., 2017). Sintesis karboksimetil dengan proses alkalisasi menggunakan $\mathrm{NaOH}$, pelarut organik (isopropanol atau etanol) serta natrium monokloroasetat atau asam trikloroasetat pada proses karboksimetilasi (Heinze \& Pfeiffer, 1999) (Md.I.H Mondal, dkk., 2015).

Alkalisasi dilakukan menggunakan $\mathrm{NaOH}$ untuk mengaktifkan gugus $\mathrm{OH}$ dari selulosa, memutus ikatan hidrogen dan mengembangkan molekul selulosa yang memperpanjang jarak molekul selulosa. Pelarut organik berperan sebagai medium reaksi yang inert, dimana proses alkalisasi dan kaboksimetilasi bisa bereaksi secara serentak dan juga dapat meningkatkan derajat substitusi. Akan tetapi konsentrasi pelarut dapat mempengaruhi nilai derajat substitusi karboksimetil selulosa (Fang Jia, dkk., 2016). Indeks polaritas pelarut dapat mempengaruhi efisiensi reaksi. Disimpulkan bahwa semakin kecil polaritas pelarut, efisiensi reaksi meningkat (Asep Handaya Saputra, dkk., 2014). Daftar jenis pelarut yang umum digunakan sebagai media reaksi dalam pembuatan karboksimetil selulosa ditunjukan oleh tabel 2.

Tabel 2. Jenis dan Polaritas Organik

\begin{tabular}{cc}
\hline Pelarut & Polaritas \\
\hline Etanol & 0,654 \\
Isobutanol & 0,552 \\
Isopropanol & 0,546 \\
\hline
\end{tabular}

Pada tabel 2 semakin kecil polaritas media reaksi juga akan meyebabkan rendahnya kelarutan $\mathrm{NaOH}$ dalam sistem karena sifat 
sistem yang non polar. Pada sistem ini, $\mathrm{NaOH}$ yang berbentuk larutan akan membentuk lapisan di sekitar selulosa dan akan menyebabkan semakin banyak jumlah $\mathrm{NaOH}$ yang terdistribusi dalam selulosa dan mengkonversi selulosa menjadi alkali selulosa (Yokota, 1985).

\section{METODOLOGI}

\section{Alat dan Bahan}

Peralatan yang digunakan dalam penelitian ini meliputi grinder THOMAS-wiley LABORATORY MILL Model 4, ayakan ukuran 60 mesh, neraca analitik, oven, desikator, stir bar, erlenmeyer, buret, batang statif, hot plate, corong kaca, gelas kimia, $\mathrm{pH}$ meter, kertas $\mathrm{pH}$, labu leher 3, gelas ukur, waterbath shakker, termometer, cawan petri, pipet tetes, kertas saring, kain saring dan blender. Bahan yang digunakan dalam penelitian ini yaitu serbuk batang pisang, air, akuades, asam formiat $\left(\mathrm{CH}_{2} \mathrm{O}_{2}\right) \quad 99,96 \%$, hidrogen peroksida $\left(\mathrm{H}_{2} \mathrm{O}_{2}\right) 50 \%$, larutan natrium hidroksida $(\mathrm{NaOH}) 15 \%$, asam trikloroasetat $\left(\mathrm{CCl}_{3} \mathrm{COOH}\right)$ $20 \%$, etanol $\left(\mathrm{C}_{2} \mathrm{H}_{5} \mathrm{OH}\right) 96 \%$, asam asetat glasial $\left(\mathrm{CH}_{3} \mathrm{COOH}\right)$ 98\%, asam klorida ( $\mathrm{HCl}) \quad 0,3 \mathrm{~N}$, indikator PP, perak nitrat $\left(\mathrm{AgNO}_{3}\right)$ $0,1 \mathrm{~N}$, dan kalium kromat $\left(\mathrm{K}_{2} \mathrm{CrO}_{4}\right)$ $5 \%$.

\section{Prosedur Penelitian}

Bubuk batang pohon pisang yang diperoleh kemudian diisolasi selulosanya. Sebanyak 10 gram serbuk batang pohon pisang dimasukan dalam labu leher tiga dan ditambahkan larutan asam formiat konsentrasi 90\%-berat dan hidrogen peroksida dengan konsentrasi 5\%berat sebagai katalisator kemudian ditambahkan akuades pada campuran tersebut, kemudian dipanaskan salama 180 menit pada suhu $100^{\circ} \mathrm{C}$ menggunakan hot plate sambil diaduk (stir bar) dengan kecapatan 300 rpm. Kemudian selulosa yang didapatkan dipisahkan dari pelarut dengan cara disaring kemudian dicuci dengan akuades sampai $\mathrm{pH}$ 7. Setelah pencucian, selulosa basah selanjutnya dikeringkan menggunakan oven pada suhu $105^{\circ} \mathrm{C}$ selama 180 menit. Selanjutnya, selulosa kering dihaluskan menggunakan blender.

Pada proses sintesis karboksimetil selulosa sebanyak 5 gram selulosa batang pohon pisang dari masingmasing sampel dimasukan ke dalam erlenmeyer, lalu ditambahkan 100 $\mathrm{ml}$ isopropanol dengan variasi konsentrasi kemurnian (70, 80, 90 dan 100\%) seagai media reaksi campuran. Setelah itu ditambahkan $20 \mathrm{ml}$ larutan $\mathrm{NaOH} 15 \%$ tetes demi tetes. Proses alkalisasi ini berlangsung selama 60 menit pada suhu $30^{\circ} \mathrm{C}$ di dalam Waterbath Shaker $100 \mathrm{rpm}$. Dilanjutkan dengan proses karboksimetilasi dengan menambahkan $20 \mathrm{~mL}$ asam trikloroasetat $20 \%$ pada suhu $55^{\circ} \mathrm{C}$ selama 180 menit. Kemudian campuran hasil proses karboksimetilasi dinetralkan dengan asam asetat (glasial) 98\%. Setelah itu disaring, dilakukan pencucian dengan etanol $96 \%$ sebanyak $10 \mathrm{~mL}$ sebanyak 3 kali pengulangan kemudian dikeringkan di dalam oven sampai beratnya konstan pada suhu $60^{\circ} \mathrm{C}$. CMC yang telah kering kemudian disimpan ditempat yang tertutup.

\section{Karakterisasi Karboksimetil Selulosa 1. Derajat Substitusi (DS)}

Uji nilai Derajat Substitusi dilakukan untuk mengetahui jumlah gugus $\mathrm{OH}$ yang tergantikan oleh $\mathrm{ClCH}_{2} \mathrm{COONa}$ sebagai penanda terbentuknya karboksimetil selulosa 
(Alia Badra Pitaloka, dkk., 2015). Banyaknya gugus hidroksil yang disubstitusi disebut degree of substitution (DS) atau derajat substitusi (Cash dan Caputo, 2010). Menurut Waring dan Parsons (2001), DS merupakan faktor utama kelarutan CMC dalam air. Karboksimetil selulosa dengan DS di bawah 0,4 bersifat swellable tetapi tidak mampu untuk larut dalam air, sedangkan di atas nilai DS tersebut karboksimetil selulosa mampu terlarut dengan hidroafinitas yang bertambah seiring dengan peningkatan Derajat Substitusi. DS menentukan kelarutan karboksimetil selulosa dan merupakan parameter utama dalam penggunaanya dalam industri pangan.

\section{2. $\mathbf{p H}$}

$\mathrm{pH}$ adalah derajat keasaman yang digunakan untuk menyatakan tingkat keasaman atau kebasaan yang dimiliki oleh suatu larutan. $\mathrm{pH}$ menjadi indikator yang menunjukan kualitas dari karboksimetil selulosa. $\mathrm{pH}$ akan menentukan kekentalan dari karboksimetil selulosa. Jika pH dibawah 1, larutan menjadi tidak homogen karena terbentuk endapan, sehingga untuk penggunaan dibidang industri khususnya industri makanan, disarankan sifat karboksimetil selulosa tidak terlalu asam yaitu $\mathrm{pH}$ 6,0 - 8,5 berdasarkan standar Food and Agriculture Organization FAO.

\section{Kemurnian}

Kemurnian dari karboksimetil selulosa dipengaruhi oleh banyaknya produk samping yang dihasilkan dari proses sintesis karboksimetil selulosa. Produk samping dari proses sintesis CMC yaitu natrium glikolat dan natrium klorida. Semakin sedikit jumlah produk samping yang dihasilkan maka akan semakin tinggi kemurnian karboksimetil selulosa. Kemurnian karboksimetil selulosa dipengaruhi oleh besarnya konsentrasi $\mathrm{NaOH}$ pada sistem dan keberadaan media reaksi. Keberadaan media reaksi pada proses sintesis karboksimetil selulosa, berperan untuk mempercepat destruksi struktur kristalin selulosa dan memudahkan substitusi $\mathrm{NaOH}$ dalam selulosa. Dengan media reaksi yang kurang tepat, keberadaan $\mathrm{NaOH}$ dalam larutan sulit untuk merusak struktur selulosa dan akan terjadi reaksi antara $\mathrm{NaOH}$ dan Natrium Kloroasetat membentuk produk samping berupa natrium glikolat dan natrium klorida. Polaritas dari media reaksi juga sangat menentukan kemurnian dari karboksimetil selulosa dihasilkan.

\section{HASIL DAN PEMBAHASAN}

Hasil isolasi selulosa menggunakan asam formiat $90 \%$-berat yang dilakukan di Laboratorium Teknologi Hasil Pertanian Politeknik Negeri Lampung yaitu $61,193 \%$, $8,383 \%$ dan $15,789 \%$. Berikut merupakan hasil sintesis karboksimetil selulosa dengan variasi konsentrasi kemurnian pelarut isopropananol pada tahap alkalisasi dengan variasi kemurnian pelarut isopropanol yaitu 70\%, 80\%, 90\% dan $100 \%$ pada tahap alkalisasi yang dilanjutkan dengan proses karboksimetalasi menggunakan asam trikloroasetat.

\section{A. Uji X-RD}

Karakterisasi menggunakan metode difraksi merupakan metode analisa yang penting untuk menganalisa suatu kristal. Karakterisasi XRD dapat digunakan untuk menentukan struktur kristal menggunakan sinar-X. Untuk melihat struktur kristalin selulosa dan alkaliselulosa. Setelah direaksikan dengan media pelarut isopropanol dan $\mathrm{NaOH} 15 \%$ akan terjadi kerusakan kristalin selulosa dan menjadi 
lebih longgar untuk mempermudah reaksi di tahap selanjutnya yaitu Karboksimetilasi.

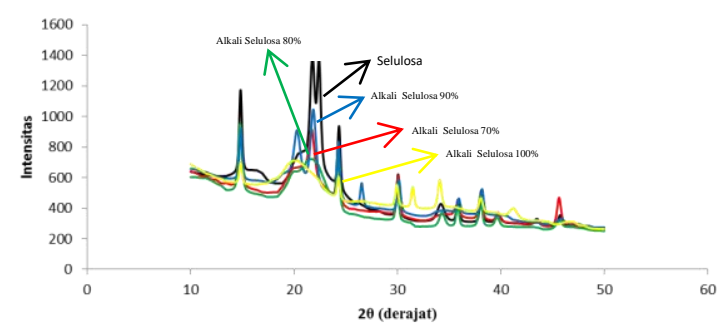

Gambar 1. Perbandingan Uji X-RD Selulosa dan Alkaliselulosa

Pada gambar 1 terlihat perbedaan struktur kristalin selulosa sebelum direaksikan dengan $\mathrm{NaOH} \quad 15 \%$ dan setelah direaksikan. Terlihat bahwa setelah direaksikan dengan variasi pelarut isopropanol $(70 \%, 80 \%, 90 \%$ dan $100 \%)$ dan $\mathrm{NaOH} 15 \%$ terjadi perbedaan kerusakan struktur kristalin selulosa berdasarkan nilai kritalinitas. Kerusakan struktur kristalin selulosa tersebut mengakibatkan lebih longgar sehingga mempermudah reaksi pada tahap selanjutnya, seperti yang dilaporkan oleh pitaloka, dkk., 2015. Pada penggunaan isopropanol $100 \%$ struktur kristalin selulosa terlihat lebih rusak yang ditandai dengan sedikitnya peak yang terbentuk dan terlihat pada hasil analisa dibandingkan dengan isopropanol $70 \%, 80 \%$ dan $90 \%$. Pada peak spectra XRD $2 \theta$ dengan intensitas yang tinggi mengindikasikan bahwa puncak tersebut berada pada daerah kristal, sedangkan pada peak dengan nilai intensitas yang rendah menunjukan daerah amorph pada selulosa dan alkaliselulosa Selain itu, banyaknya kerusakan struktur kristalin yang disebabkan oleh media pelarut dapat terlihat dari hasil perhitungan persen derajat kristalinitas menggunakan "Height Peak Method" (Park, dkk., 2010).

\section{B. Pengaruh terhadap Nilai Derajat Substitusi}

Derajat subtitusi dapat menentukan kelarutan karboksimetil selulosa. Derajat Substitusi adalah jumlah rata-rata gugus per anhidroglukosa unit yang disubstitusikan oleh gugus lain. Semakin besar derajat subsitusi maka kualitas karboksimetilasi semakin baik, karena kelarutannya dalam air semakin besar (Wijayanti, dkk, 2005). Apabila gugus yang menggantikan berupa satu gugus anhidroksil pada tiap unit anhidroglukosa diesterifikasi dengan satu buah gugus asetil, nilai DS sebesar 1. DS yang dihasilkan yaitu $0.083-0.207$ (Nisa, dkk., 2014). Berikut merupakan gambar pengaruh kemurnian isopropanol terhadap nilai derajat substitusi.

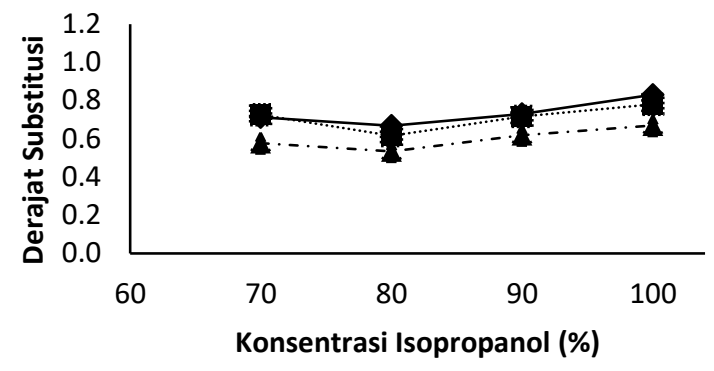

Gambar 2. Pengaruh konsentrasi isopropanol terhadap derajat substitusi karboksimetil selulosa

Berdasarkan gambar 2 terlihat bahwa pada produk karboksimetil selulosa dengan derajat subtitusi yang terendah diperoleh pada sampel S-3 dengan kandungan selulosa $52 \%$ yaitu 0,534 dengan pola grafik yang sama antar perlakuan konsentrasi kemurnian isopropanol terhadap nilai derajat substitusi yaitu turun kemudian naik dengan nilai derajat substitusi tertinggi yaitu 0,831. Diduga nilai derajat substitusi yang rendah ini disebabkan oleh $\mathrm{NaOH}$ pada tahap alkalisasi cenderung bereaksi dengan lignin dan hemiselulosa (Pitaloka, dkk., 2015). Diketahui bahwa pada kandungan selulosa $52 \%$ pada sampel penelitian ini memiliki kandungan hemiselulosa dan lignin yang paling tinggi diantara kedua sampel yang ada yaitu sebesar 10,349\% dan $25,509 \%$.

Kandungan hemiselulosa yang masih ikut terbawa alfa selulosa setelah proses isolasi selulosa akan membuat larutan 
$\mathrm{NaOH}$ yang digunakan ikut melarutkan sebagian hemiselulosa. Hal ini mengakibatkan proses pengembangan selulosa terhambat, dimana proses pengembangan selulosa erat hubungannya dengan proses selanjutnya yaitu proses karboksimetilasi. Kondisi karboksimetilasi akan optimum jika pengembangannya optimum. Selain itu, diduga terdapat peranan variasi pelarut isopropanol pada proses sintesis karboksimetil selulosa sehingga penghancuran struktur kristalin menjadi struktur amorf akan membuat struktur amorf berorientasi kembali dan bergabung untuk membentuk struktur kristalin lain.

Hal ini akan membuat struktur selulosa lebih padat dan sulit ditembus oleh reagen kimia. Transformasi dalam struktur selulosa dapat menjadi alasan untuk peningkatan nilai derajat substitusi karboksimetil selulosa yang dihasilkan dengan media reaksi. Sejalan dengan hasil analisis X-RD bahwa bentuk struktur yang paling amorf berdasarkan variasi komposisi pelarut isopropanol berada pada konsentrasi $100 \%$ dengan nilai kristalinitas $13,91 \%$ dan nilai Derajat Substitusi tertinggi yaitu 0,831. Hubungan antara banyaknya kandungan air yang ada pada tahap pembuatan karboksimetil selulosa (alkalisasi) memiliki pengaruh terhadap nilai derajat substitusi karboksimetil selulosa. Pada penelitian ini kandungan air terdapat pada variasi isopropanol sebagai media reaksi. Seperti yang dilaporkan oleh Hendayani dan Musianti (1993) bahwa proses alkalisasi dalam media air akan menghasilkan karboksimetil yang kurang homogen, sehingga nilai derajat substitusi dari karboksimetil selulosa yang dihasilkan rendah. Akan tetapi pada penelitian ini terdapat nilai derajat substitusi yang lebih tinggi dibandingkan dengan kandungan air pada media reaksi yang lebih banyak yaitu pada pelarut isopropanol $70 \%$.

\section{Pengaruh terhadap Nilai Ph}

Karakteristik karboksimetil selulosa yang berkaitan dengan kualitas yang baik selanjutnya adalah $\mathrm{pH}$. Karboksimetil selulosa dapat berfungsi bersama dengan kebanyakan gom lain yang larut dalam air, dan tidak terpengaruh oleh adanya kation yang dapat menghasilkan garam yang larut. Nilai pH dari karboksimetil selulosa yang dihasilkaan dari berbagai konsentrasi kemurnian isopropanol dapat dilihat pada Gambar 3.

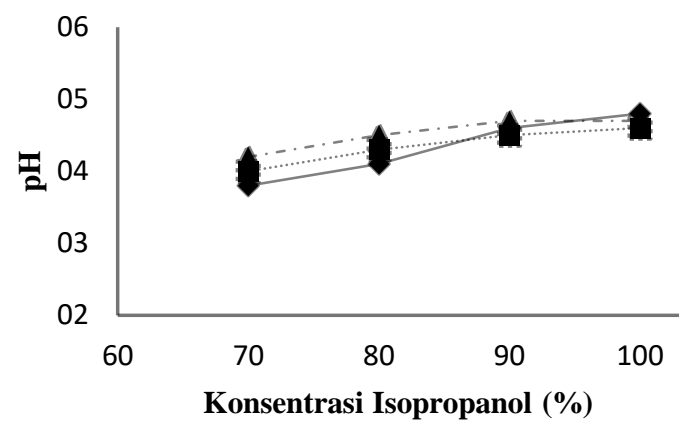

Gambar 3. Pengaruh Konsentrasi Isopropanol terhadap nilai $\mathrm{pH}$ Karboksimetil Selulosa

Gambar 3 merupakan grafik nilai $\mathrm{pH}$ karboksimetil selulosa yang dihasilkan akibat perlakuan perbedaan konsentrasi kemurnian isopropanol. Semakin tinggi konsentrasi kemurnian isopropanol yang diberikan maka $\mathrm{pH}$ yang dihasilkan juga akan meningkat. Nilai $\mathrm{pH}$ dari CMC menjadi pertimbangan dalam penggunaannya. Jika nilai $\mathrm{pH}<1$ larutan menjadi tidak homogen karena terbentuk endapan. $\mathrm{pH}$ larutan CMC $1 \%$ biasanya 7 - 8,5 dan pada rentang 5-9 tidak terlalu berpengaruh pada viskositas CMC ( Wijayani, dkk, 2005).

Nilai $\mathrm{pH}$ tertinggi dan terendah berturut-turut yaitu 4,8 dan 3,8, yang diperoleh dari karboksimetil selulosa yang disintesa dari kandungan selulosa $61 \%$. Sehingga, $\mathrm{pH}$ yang diperoleh dari penelitian ini belum memenuhi nilai $\mathrm{pH}$ SNI yaitu 6,0 - 8,0 untuk mutu I dan 6,08 , untuk mutu II. Masih rendahnya nilai $\mathrm{pH}$ tersebut, dikarenakan belum optimalnya proses netralisasi 
menggunakan asam asetat pada tahap pemurnian. Dimana tingginya nilai $\mathrm{pH}$ kisaran 12-14 yang didapat pada saat penelitian sebelum tahap netralisasi mengakibatkan pada belum optimalnya banyaknya asam asetat dengan kisaran $\mathrm{pH}$ 2 - 3 yang harus digunakan untuk menetralisasi produk karboksimetil selulosa. Selain itu, pada produk karboksimetil selulosa setelah pengeringan masih tercium cukup tajam dari asam asetat. Berdasarkan nilai $\mathrm{pH}$ karboksimetil selulosa yang didapat yaitu $\leq 5$ menunjukan rendahnya kekentalan dari produk tersebut (Nisa, dkk., 2014).

\section{Pengaruh terhadap Kemurnian Karboksimetil Selulosa}

Kemurnian merupakan salah satu karakterisasi karboksimetil selulosa dan sebagai indikator karboksimetil selulosa yang baik. Kemurnian ini dipengaruhi oleh besarnya produk samping yang dihasilkan selama proses pembuatan karboksimetilasi selulosa. Produk samping yang dihasilkan selama tahap sintesa adalah natrium klorida dan natrium glikolat. Sehingga, tingginya kemurnian dari karboksimetil selulosa disebabkan oleh sedikitnya produk samping yang dihasilkan.

Keberadaan media reaksi atau pelarut yang kurang tepat, membuat keberadaan $\mathrm{NaOH}$ dalam larutan sulit untuk merusak struktur selulosa dan akan terjadi reaksi pembentukan produk samping (Pitaloka, dkk., 2015). Penggunaan media reaksi atau pelarut yang kurang tepat, membuat larutan $\mathrm{NaOH}$ sulit untuk merusak struktur selulosa, sehingga menyebabkan $\mathrm{NaOH}$ bereaksi dengan asam trikloro asetat membentuk $\mathrm{NaCl}$ Kemurnian karboksimetil selulosa yang dihasilkan dari berbagai variasi isopropanol dapat dilihat pada gambar 4 .

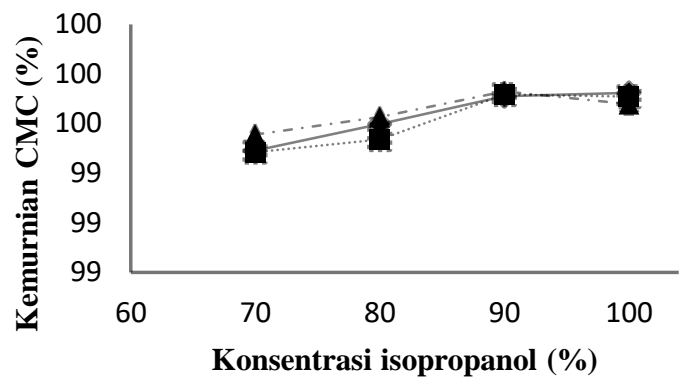

Gambar 4. Pengaruh Konsentrasi Isopropanol terhadap Kemurnian Karboksimetil Selulosa

Berdasarkan grafik pada gambar 4 menunjukan pola yang sama untuk berbagai kandungan selulosa dan variasi konsentrasi kemurnian isopropanol. Kemurnian karboksimetil selulosa tertinggi yang dihasilkan yaitu $99,7 \%$ pada konsentrasi kemurnian isopropanol 90\% untuk masing-masing kandungan selulosa. Kadar CMC > 99,5\% diklasifikasikan sebagai mutu 1 dan digunakan dalam industri makanan, obat-obatan dan kosmetik, sedangkan bila kurang dari harga tersebut digunakan dalam industri pertambangan atau petroleum.

Kemurnian Karboksimetil selulosa pada penelitian ini menunjukan kenaikan pada konsentrasi kemurnian isopropanol $90 \%$ dan penurunan pada konsentrasi kemurnian isopropanol $100 \%$ untuk berbagai kandungan selulosa. Selain itu, pada hasil penelitian menunjukan pola yang sama pada konsentrasi isopropanol $90 \%$ dan $100 \%$ pada nilai derajat substitusi terhadap kemurnian karboksimetil selulosa yang didapat. Pada teknik pemurnian yang masih sederhana, diduga dapat mempengaruhi tingkat kemurnian karboksimetil selulosa yang didapat (Hutomo, 2012 dalam Ferdiansyah, dkk., 2016). Akan tetapi kemurnian kerboksimetil selulosa yang dihasilkan sudah memenuhi SNI (Standar Nasional Indonesia). 


\section{SIMPULAN DAN SARAN}

Berdasarkan penelitian yang telah dilakukan dapat disimpulkan sebagai berikut:

- Kondisi optimum sintesis CMC (Carboxymethyl Cellulose) ditinjau melalui parameter nilai derajat substitusi dan kemurnian CMC berturut-turut $0,7-0,8$ dan $99,5 \%$ 99,7\% yang dihasilkan memenuhi persyaratan SNI mutu I yang dapat digunakan pada industri pangan dari kandungan selulosa $61 \%$ dan $55 \%$ batang pisang diperoleh pada konsentrasi media reaksi isopropanol $100 \%$. Sedangkan untuk karakterisasi nilai $\mathrm{pH}$ belum memenuhi standar SNI.

- Pengaruh konsentrasi media reaksi isopropanol pada tahap alkalisasi terhadap nilai derajat substitusi dan kemurnian kemurnian $\mathrm{CMC}$ dari batang pisang dapat dinyatakan bahwa semakin tinggi konsentrasi konsentrasi isopropanol maka nilai derajat substitusi dan kemurnian CMC akan semakin meningkat, hal tersebut disebabkan oleh semakin banyaknya kandungan air pada sintesis CMC

\section{DAFTAR PUSTAKA}

Adinugraha P. Mario, Djagal W. Marseno, Haryadi. 2005. "Synthesis and Characterization of Sodium Carboxymethylcellulose from Canvedish Banana Pseudon Stem (Musa Cavendishii LAMBERT).

A.B.M.F. Alam, Md.I.H. Mondal, J. Appl. Polym. Sci. 128 (2) (2013) 12061212.

Adis Mahendra., Mitarlis. 2017. "Synthesis and Characterization of Carboxymethyl Cellulose (CMC) From Water Hyacinths Celullose" UNESA Jounal of Chemistry Vo. 6 No. 1, Januari 2017
Alia Badra Pitaloka., Nur Anis Hidayah, Asep Handaya Saputra, Mohammad Nasikin. 2015. "Pembuatan CMC dari Selulosa Eceng Gondok dengan Media Reaksi Campuran Larutan Isopropanol-Isobutanol unutuk Mendapatkan Viskositas dan Kemurnian Tinggi”. Jurnal Integrasi Proses Vol. 5 No. 2 (Juni 2015) 108 - 144.

Ayuningtiyas, S., Desiyana, F. D., dan Siswarni, MZ. (2017). Pembuatan Karboksimetil Selulosa dari Kulit Pisang Kepok dengan Variasi Konsentrasi Natrium Hidroksida, Natrium Monokloroasetat, Temperatur dan Waktu Reaksi. Jurnal Teknik Kimia USU. 6(3): 47.

Bahri, S. (2015). Pembuatan Pulp dari Batang Pisang. Jurnal teknologi kimia unima. 4(2): 3 dan 38.

Candido, R.G. \& A.R. Goncalves. 2016. "Synthesis of cellulose acetate and carboxymethylcellulose from sugarcane straw". Carbohydrate Polymers 152 (2016) 679 - 686.

Chumee, J., \& Seeburin, D. (2014). Cellulose extraction from pomelo peel: synthesis of carboxymethylcellulose.

International Journal of Chemical, Nuclear, Materials and Metallurgical Engineering, 8, 406408.

Fan Lihong, Xiaoyu Zhou, Penghui Wu, Weigou Xie, Hua Zheng, Wang Tan, Shulua Liu, Qingyuan Li. (2014). "Preparation of Carboxymetyl Cellulose Sulfates and its Application as Anticoagulant and Wound Dressing". International Journal of Biological Macromolecules 245253 
Gyanesh Joshi, Sanjay Naithani, V.K. Varshney, Surendra S. Bisht, Vika Rana, P.K. Gupta. (2014). "Synthesis and Characterization of Carboxymethyl Cellulose from Office Waste Paper : A Greener Approach towards waste management". Elsevier. Waste Management.

Hasibuan, I. F. (2016). Pemanfaatan Jerami Padi (Oryza sativa L) sebagai Bahan Baku Pembuatan Karboksimetil Selulosa. Skripsi. Medan: Universitas Sumatera Utara. Halaman 2.

Hong K.M. (2013). Preparation and characterization of carboxymethyl cellulose from sugarcane bagasse. Project Report, Malaysia: Tunku Abdul Rahman Universiti.

Hutomo, G. S., (2012), Sintesis dan KarakterisasiTurunan Selulosa Dari Pod Husk Kakao (Theobroma cacao L.). Disertasi. Program Pasca Sarjana UGM.Yogyakarta.

Jia Fang., Liu Hong-jie, Zhang, Guo-gang. (2016). "Preparation of carboxymethyl cellulose from cornob". Procedia Enviromental Sciences 31 (2016) 98-102. The Tenth International Conference on Waste Management and Technology (ICWMT).

Mokhamad Khoiron F., Djagal W. Marseno, Yudi Pranoto. (2016). "The Study of Carboxymethyl Cellulose (CMC) from Palm Midrid As Halal Food Additives Diversification". Jurnal Aplikasi Teknologi Pangan 5 (4).

Mondal Md. Ibrahim H., Mst. Sarmina Yeasmin, Md. Saifur Rahman. (2015). "Preparation of food grade carboxymetyl cellulose from corn husk agrowaste". International Journal of Biological Macromoleculer
Mohapatra, D., Mishra, S., dan Sutar, N. (2010). Banana and its by-product utilization: an overview. Journal of Scientific \& Industrial Research: 326.

Muharni Tuo. (2016). "Kandungan Hemselulosa, Selulosa dan Lignin Silase Pakan Lengkap Berbahan Utama Batang Pisang (Musa Paradisiaca) Dengan Lama Inkubasi Yang Berbeda”. Fakultas Pertanian Universitas Hasanuddin. Makasar.

Mukkades Karatas and Nurhan Arslan. (2016). "Flow behaviours of cellulose and carboxymethyl cellulose from grapefruit peel".Food Hydrocolloids. Faculty of Engineering, Departement of Chemical Engineering, Firat University, 23279 Elazig, Turkey.

Muzakkar, M. Z., Tamrin, Nur, R., dan Ratna. (2017). Sintesis dan Karakterisasi CMC (CARBOXYMETHYL

CELLULOSE) yang Dihasilkan dari Jerami Padi. Prosiding Seminar Nasional FKPT-TPI 2017 Kendari, Sulawesi Tenggara, 2021 September 2017: 401 dan 404.

Nisa, D. and W. D. R. Putri. (2014). Cellulose utilization in cacao pod husk (Theobroma cacao L.) as raw material for CMC (carboxtmethyl cellulose) synthesis. Jurnal Pangan dan Agroindustri. 2(3):34-42.

Noor Haleem., Muhammad Arshad, Muhammad Shahid, Muhammad Ashraf Tair. (2014). "Synthesis of carboxymethyil cellulose from waste of cotton ginning industry". Carbohydrate Polymers 3 (2014) 249-255.

Park, J.O. Baker, M.E. Himmel, P.A. Parilla, D.K. JohnsonCellulose crystallinity index: measurement techniques and their impact on 
interpreting cellulase performance Biotechnol. Biofuels, 3 (2010), pp. 1-10.

P. Lestari, T.N. Hidayati, S. H. Indah, D. W. Marseno. (2013). "Pengembangan Teknologi Pembuatan Biopolimer Bernilai Ekonomi Tinggi dari Limbah Tanaman Jagung (Zea mays) untuk Industri Makanan : CMC (Carboxymethyl Cellulose)". EProceeding Pimnas PKM-P 2013.

Prepared at the 74th JECFA (2011) and published in FAO JECFA Monographs $11 \quad$ (2011), superseding specifications prepared at the 55th JECFA (2000), published in the Combined Compendium of Food Additive Specifications, FAO JECFA Monographs 1 (2005). An ADI 'not specified' was established for modified celluloses at the 35 th JECFA (1989.

Rachtanapun, P., S. Luangkamin, K. Tanprasert and R. Suriyatem. 2012. Carboxymethyl cellulose film from durian rind. Lwt-food science and technology.48(1). 5258.

Saputra, A. H., Hapsari, M., \& Pitaloka. A. B. (2015). Synthesis and characterization of CMC from water hyacinth cellulose using isobutyl-isopropyl alcohol mixture as reaction medium. Contemporary Engineering Sciences, 8, 157-1582.

Saputri Ayuningtyas, Feni Dwi Desiyana, Siswarni MZ. (2017). "Synthesis Of Carboxymethyl Cellulose From Banana Peel With Variations Of Sodium Hydrocide And Sodium Monochloroacetat Concentration, Temperature And Reaction Time". Jurnal Teknik Kimia Universitas Sumatera Utara, Departemen Teknik Kimia, Fakultas Teknik,
Universitas Sumatera Utara Vol. 6, No.3.

Singh, R.K. and Singh, A.K., 2012. "Optimization of reaction conditions for preparing carboxymethyl cellulose from corn cobic agricultural waste". Waste Biomass Valor.

Sri Anggrahini, Djagal Wiseso Marseno, Agus Setiyoko, Amalia Wahyuningtyas. (2017). "Carboxymethyl cellulose (CMC) from Snake Fruit (Salaca edulis Reinw) Kernel of "Pondoh Super" : Synthesis and Characterization". Indonesia Food and Nutrition Progress, Vol. 14, Issue 2. ISSN: 0854-6177.

Yeasmin Mst. Sarmina \& Md. Ibrahim H. Mondal.2015. "Syntesis of Highly Substituted Carboxymethyl Cellulose Depending on Cellulose Particle Size". International Journal Biological Macromolecules 80 (2015) 725731.

Zhixiang Cai, Juan $\mathrm{Wu}$, Baiqiao Du, Hongbin Zhang. 2016. "Impact of distribution of carboxymethyl substituents in the stabilizer of carboxymethyl cellulose on the stability of acidified milk drinks". Food Hydrocolloids. 


\section{Halaman Kosong}

